\title{
I slamic Perspective of Anti-Violence Education for Early Childhood in The Family Environment
}

\author{
Luluk A tirotu Zahroh
}

Received: 20052016 / Accepted: 2505 2016 / Published online: 13122016

๑ 2016 Association of Indonesian Islamic Kindergarten Teachers Education Study Program

\begin{abstract}
Anti-violence education implemented in various educational environment, equally important the family environment. The impact of violence against spiritual emotional intelligence development of children leads to the negative things. Include that realize or not, violence that showed by parents have instilled hatred and excessive fear in children. Violence will infuse stubborn and rude in children, give wound in the hearts of children until they are adults. Islam teaches anti-violence education, especially on the early chilhood education, have to carry out with great affection. M any verses of the holy Koran which instruct to educate children with affection. The term like qaulan layyinan, qaulan ma'rufan and so on are some command to teach and interact with students full with love and through the good ways.
\end{abstract}

Keyword: anti-violence education, early chilhood.

\begin{abstract}
A bstrak Pendidikan anti kekerasan diterapkan di berbagai lingkungan pendidikan, dan tidak kalah pentingnya yaitu lingkungan keluarga. Dampak kekerasan orang tua terhadap perkembangan kecerdasan emosional spiritual anak ini mengarah pada hal-hal yang negatif. Dampak tersebut diantaranya adalah: sadar atau tidak kekerasan yang dilakukan orang tua telah menanamkan kebencian dan rasa takut yang berlebihan pada diri anak. Kekerasan akan menanamkan sifat keras dan sikap kasar pada diri anak, membekaskan luka di hati anak hingga mereka dewasa. Islam mengajarkan pendidikan yang bersifat anti kekerasan, apalagi dalam konteks mendidik anak usia dini, dilakukan dengan penuh kasih sayang. Banyak ayat al-Qur'an yang memerintahkan mendidik anak dengan kasih sayang kepada putra-putranya yang masih kecil. Bahasa qaulan layyinan, qaulan ma'rufan dan sebagainya merupakan perintah untuk mendidik dan berinteraksi dengan anak didik dengan penuh kasih sayang dan cara yang baik.
\end{abstract}

Kata Kunci: Pendidikan Anti Kekerasan, Anak Usia Dini.

\section{Pendahuluan}

Manusia lahir dibekali dengan berbagai potensi dan kemampuan yang berbeda-beda. Sebagai khalifah Allah di bumi, manusia memiliki kewajiban untuk mengembangkan potensi yang mereka miliki. Oleh karena itu, manusia dalam kehidupannya memerlukan pendidikan untuk mengembangkan potensi fitrahnya, baik fisik maupun psikis agar manusia menjadi insan yang kamil. Jelaslah bahwa pendidikan memliki peranan yang sangat dominan, terlebih lagi pendidikan dalam keluarga, karena pendidikan keluarga merupakan pendidikan yang pertama dan utama. Orang tua sebagai pendidik di lingkungan keluarga memiliki tanggung jawab yang 
besar terhadap perkembangan anak-anaknya. Sebagaimana yang ditulis oleh $\mathrm{H}$ asbullah (2003:40) bahwa kewajiban orang tua tidak hanya sekedar memelihara eksistensi anak untuk menjadikannya kelak sebagai seorang pribadi, tetapi juga memberikan pendidikan anak sebagai individu yang tumbuh dan berkembang.

Pemahaman orang tua terhadap fase-fase perkembangan jiwa anaknya sangat diperlukan, terlebih lagi komunikasi atau pergaulan orang tua terhadap anak atau yang sebaliknya anak terhadap orang tuanya akan membawa dampak terhadap kehidupan anak di masa yang akan datang. Hal tersebut jelas merupakan suatu tanggung jawab orang tua.

Pada kenyataannya, orang tua sering merasa memiliki jiwa dan raga anaknya tanpa kecuali disertai keinginan yang kuat dan anggapan bahwa anak sebagai hasil produksi orang tua, sehingga harus selalu sama tingkah lakunya dengan kehendak orang tua dan dapat diperlakukan apa saja. Tidak jarang orang tua menggunakan kekerasan baik fisik maupun psikis dalam mengerjakan fungsi dan perannya sebagai pendidik anak dalam lingkungan keluarga. Mereka tidak menyadari akibat perbuatannya akan berdampak negatif terhadap perkembangan anaknya terutama perkembangan kecerdasan emosional dan spiritualnya.

Pendidikan dalam keluarga semestinya digunakan untuk mendewasakan kecerdasan emosional seorang anak, karena dengan memiliki kecerdasan emosional yang baik anak akan mampu mengendalikan dirinya dan mampu meraih sukses dan bahagia dalam hidupnya di masa yang akan datang. Sebagaimana yang dikutip oleh Hamzah dari Goleman mengatakan bahwa:

Orang yang secara emosional cakap yang mengetahui dan menangani perasaan mereka dengan baik, yang mampu membaca dan menghadapi perasaan orang lain dengan efektif memiliki keuntungan dalam setiap bidang kehidupan, entah dalam hubungan asmara dan persahabatan atau dalam menangkap aturan-aturan tidak tertulis yang menentukan keberhasilan dalam politik organisasi. Orang dengan keterampilan emosional yang berkembang baik berarti kemungkinan besar ia akan bahagia dan berhasil dalam kehidupan, menguasai pikiran-pikiran yang mendorong kehidupan mereka (H amzah, 2006:73).

Pendidikan dalam keluarga dikatakan merupakan pendidikan penting dan yang utama. M aka dari itu hendaklah dalam keluarga dipenuhi kasih sayang, karena kasih sayang akan dapat berpengaruh kepada kecerdasan emosional anak. Sebagaimana yang ditulis oleh Singgih D. Gunarsa dan Y Singgih D. Gunarsa, hubungan kasih sayang akan mendekatkan anak dengan orang tuanya, memudahkan orang tua memberi hadiah dan hukuman yang sepadan. A nak juga akan lebih mudah menerima nilai-nilai orang tuanya dan menirunya.

Selain perkembangan kecerdasan emosional, dalam mendidik anaknya, orang tua perlu memperhatikan kecerdasan spiritual anak tersebut. Kecerdasan spiritual merupakan kecerdasan yang ada pada diri manusia dalam hubungannya dengan penciptanya. Dengan kecerdasan spiritual ini manusia dapat menjadi orang yang sadar dengan kekurangan dan bersikap qona'ah juga mempunyai akhlak yang terpuji. Orang yang mempunyai kecerdasan spiritual yang tinggi akan selalu merasa bahwa ia diamati oleh Tuhannya. Kecerdasan spiritual ini dapat ditingkatkan atau dikembangkan dengan pendidikan dalam keluarga, karena tujuan pendidikan dalam keluarga sebagaimana ditulis oleh Hasbullah adalah "sebagai peletak dasar bagi pendidikan akhlak dan pandangan hidup keagamaan". O leh karena itu, orangtua wajib memikul tanggung jawab untuk memberikan pendidikan yang benar kepada anak di rumah dan di dalam lingkungan keluarga, dan memelihara mereka dengan cinta dan kasih sayang menurut etika Islam. 
Jelaslah bahwa orang tua memiliki peranan yang sangat penting dalam membentuk kepribadian anak-anaknya. Namun pada kenyataannya tidak sedikit orang tua yang belum mampu menjalankan peranannya sebagai orang tua yang baik. Tindak kekerasanpun biasa mereka lakukan dalam memberikan peringatan atau hukuman pada anak. Dalam lingkungan keluarga sebagaimana yang ditulis oleh Elfi M uawanah, bahwa "remaja perlu menaati peraturan dan tata cara yang berlaku. Di samping peraturan tertentu perlu adanya semacam punishment yang dibuat orang tua terhadap pelanggaran tata tertib keluarga". Akan tetapi punishment tersebut tidak dapat dijadikan alasan orang tua mengadakan kekerasan kepada anaknya. Hukuman yang diberikan hendaknya berupa sesuatu yang bersifat mendidik ke arah perbaikan, bukan sesuatu yang menyakitkan seperti kekerasan. M aka dari itu, perlu adanya pendidikan anti kekerasan pada lingkungan keluarga.

Banyak sekali fenomena kekerasan yang dilakukan orang tua terhadap anaknya. Sebagaimana diutarakan di atas, bahwa orang tua sering melakukan kekerasan kepada anaknya dengan alasan memberikan hukuman kepada mereka karena telah melakukan kesalahan atau berperilaku buruk. Padahal seharusnya, sebagaimana diungkapkan oleh Muhammad Sa'id M ubayyadh, "hukuman tidak dimaksudkan menyakiti fisik dan mental anak, seperti yang sering dilakukan secara berlebihan oleh para orang tua dalam mendidik anak-anaknya”. Kekerasan yang dilakukan oleh orang tua akan berdampak negatif terhadap perkembangan anak, terlebih pada anak usia sekolah dasar (6-12 tahun). Anak menjadi kurang hormat terhadap orang tua, berani mengabaikkan perintah dan melakukan sesuatu karena terpaksa. A nak akan melakukan perbuatan terpuji bukan karena kesadaran mereka melainkan hanya karena ingin memuaskan keinginan orang tua saja dan menghindari rasa sakit dari perlakuan keras mereka.

$\mathrm{Hal}$ tersebut terjadi karena ketika memasuki usia sekolah dasar, anak sudah mulai mengenal dunia luar di luar lingkungan keluarga. Mereka mulai mengenal guru sebagai pendidik di lingkungan sekolah dan mereka juga mengenal teman sebaya yang menjadi teman mereka di sekolah. Mereka mulai beradaptasi dengan lingkungan baru yang secara otomatis juga memberikan banyak pengaruh terhadap perkembangan kecerdasan dan kepribadian mereka.

Di usia sekolah ini, anak relatif lebih mudah dididik dari masa sebelumnya karena mereka sudah mulai memiliki kematangan baik secara fisik, intelektual, moral maupun sosialnya. Mereka mulai mengenal dan menerima otoritas atau kekuasaan dari orang lain selain orang tuanya yaitu otoritas guru di sekolah. M ereka mulai beradaptasi dengan peraturan-peraturan yang ada di sekolah seperti ketertiban dan kedisiplinan hidup yang secara berangsur-angsur akan dikuasainya. Tidak heran jika anak terkadang lebih taat dan percaya terhadap apa yang disampaikan guru di sekolah, ingin menyesuaikan diri dengan teman-teman sebayanya dengan berperilaku sesuai yang diharapkan kelompoknya meskipun hal itu bertentangan dengan yang diharapkan oleh orang tua mereka.

Dalam kondisi anak seperti tersebut di atas, hendaknya orang tua sebagai pendidik pribadi yang pertama mampu memahami kondisi anaknya yang sedang berkembang. Orang tua harusnya memberikan bimbingan dan pengarahan yang positif terhadap anak-anak mereka agar anak merasa lebih diakui dan dihargai, sehingga sikap dan tingkah laku mereka dapat terarah pada perbuatan yang terpuji, mampu mengendalikan diri dalam pergaulan dan dapat menjalin hubungan baik dengan orang-orang yang ada di sekitarnya. Selain itu harusnya orang tua juga lebih giat menanamkan nilai-nilai agama dan lebih mendisiplinkan anak dalam menjalankan kewajiban ibadahnya. Hal ini penting karena pada usia sekolah dasar, anak akan lebih disibukkan dengan kegiatan ataupun tugas-tugas yang mereka dapat dari sekolah. Oleh karena 
itu, bimbingan, pengarahan dan perhatian orang tua sangat diutamakan agar kecerdasan emosional spiritual anak bisa berkembang baik secara maksimal sesuai dengan fase perkembangannya.

Pastinya ada banyak hal yang bisa memicu atau menjadi penyebab orang tua melakukan tindak kekerasan dalam mendidik anak-anaknya. Bisa saja hal itu disebabkan oleh kondisi ekonomi. Sering kita jumpai orang tua yang menghadapi kesulitan ekonomi cenderung mengalami tekanan dan mudah terpancing amarah yang kemudian meluapkan emosi pada anak-anak mereka, terlebih jika mereka merasa anak-anaknya sulit diatur atau mengabaikkan perintah. Selain itu, latar belakang pendidikan orang tua yang rendah juga bisa menyebabkan mereka lebih sering menggunakan kekerasan dalam mendidik anak-anak. Orang tua yang memiliki pemikiran kolot dan memiliki keterbatasan pengetahuan tentang cara mendidik anak yang baik bisa saja menggunakan kekerasan dalam mendidik anak-anaknya.

Ketidak mampuan orang tua mengendalikan emosinya, dapat berakibat fatal terhadap perkembangan anak-anak mereka terutama perkembangan emosional dan spiritualnya. Berbagai bentuk perlakuan keras orang tua sering dijadikan alternatif untuk memberikan hukuman dan peringatan pada anak-anak mereka. Pukulan, tamparan, celaan, umpatan ataupun kata-kata yang tidak selayaknya sering dijadikan wujud hukuman orang tua terhadap anak-anak mereka. Hal-hal tersebut tentunya akan menimbulkan rasa sakit bagi anak, baik secara fisik maupun psikis yang tentunya akan berdampak negatif terhadap perkembangan kepribadiaannya. Namun pada kenyataannya masih banyak orang tua yang tidak memiliki kesadadaran dan kepedulian akan dampak kekerasan yang mereka lakukan terhadap anak-anak mereka.

\section{Konsep D asar Kekerasan}

Secara harfiah kekerasan diartikan sebagai sifat atau hal yang keras; kekuatan; paksaan". Sedangkan secara terminologi kekerasan berarti "perbuatan seseorang atau sekelompok orang yang menyebabkan cedera atau matinya orang lain atau menyebabkan kerusakan fisik atau barang orang lain. Segala macam perbuatan yang menimbulkan penderitaan bagi orang lain dapat diartikan sebagai kekerasan.

Oleh karena itu, pengertian kekerasan itu mencakup keseluruhan makna dari suatu penderitaan yang diderita oleh manusia sebagai pribadi dan masyarakat sebagai obyek yang luas. Secara umum dan luas makna kekerasan mencakup seluruh perbuatan yang menimbulkan penderitaan baik secara fisik, mental maupun psikologis manusia.

\section{Konsep D asar Pendidikan Anti Kekerasan}

Menurut UU Nomor 20 tahun 2003, pendidikan adalah usaha sadar dan terencana untuk mewujudkan suasana belajar dan proses pembelajaran agar peserta didik secara aktif mengembangkan potensi dirinya untuk memiliki kekuatan spiritual keagamaaan, pengendalian diri, kepribadian, kecerdasan, akhlak mulia, serta keterampilan yang diperlukan dirinya, masyarakat, bangsa, dan negara. Sedangkan kekerasan adalah suatu perbuatan terhadap seseorang yang mengakibatkan kesengsaraan atau penderitaan secara fisik, psikologis, seksual, finansial, spiritual. Sehingga pendidikan anti kekerasan dapat didefinisikan sebagai suatu usaha sadar untuk mewujudkan suatu suasana belajar tanpa harus menimbulkan kesengsaraan/ kerusakan baik secara fisik, psikologis, seksual, finansial maupun spiritual. Berikut ini penulis jelaskan mengenai jenis-jenis kekerasan antara lain sebagai berikut: 


\section{Kekerasan Fisik}

Kekersan fisik ini dalam bahasa Inggris diistilahkan sebagai physical abuse yang merupakan "perilaku yang menyakitkan secara fisik seperti memukul, membakar, meracuni/ obat salah, menenggelamkan dan lain-lain". Dalam realitanya, hal-hal tersebut sudah menjadi pandangan umum yang dianggap wajar dan biasa. Banyak orang tua yang menganggap perlakuan seperti itu merupakan hal yang lumrah dan menjadi bagian dari bentuk pendidikan agar anak tidak menjadi liar dan nakal.

Sebagaimana yang dikatakan oleh Muhammad Thohir bahwa "dalih yang sering digunakan adalah karena anak nakal atau kekerasan itu merupakan bagian dari proses dalam pendidikan itu sendiri". Tidak heran jika akhirnya muncul persepsi bahwa "seorang anak tidak disikapi atau diperlakukan dengan keras, maka tidak akan terjadi perubahan di dalam dirinya".

Jika anak membantah atau melakukan kesalahan, seringkali tidak segan orang tua langsung menampar, bahkan jika orang tua benar-benar tidak bisa menahan kesabaran, mereka tega memukul anak dengan benda keras seperti sapu, kayu dan sebagainya. M ereka menganggap hal tersebut salah satu cara untuk mendisiplinkan anak, padahal hal-hal demikian merupakan suatu bentuk kekerasan yang tidak boleh digunakan dalam mendidik anak karena kekerasan itu menyakitkan dan akan berpengaruh pada kepribadian anak kelak.

\section{Kekerasan Psikologis}

Selain kekerasan fisik yang tidak kalah membahayakannya adalah kekerasan psikologis atau kekerasan psikis. Kekerasan ini menimbulkan penderitaan batin dan jiwa bagi diri anak. Kekerasan ini pada kenyataannya lebih menyakitkan karena dampaknya akan membekas dalam diri anak hingga dewasa. Kekerasan psikis tersebut lebih mengarah pada verbal abuse atau "penganiayaan anak melalui kata-kata seperti hinaan, celaan, kritikan, bahkan ancaman sehingga anak kehilangan harga diri dan kepercayaan dirinya".

Tekanan dan paksaan dari orang tua juga merupakan bentuk kekerasan psikis. Sebagaimana yang dikatakan oleh Nurani Soyomukti bahwa "kekerasan psikologis juga hadir berupa wacana pemahaman dan ideologi yang salah yang dicekokkan terhadap anak, ukuranukuran yang belum tentu baik tetapi seringkali dipaksakan melalui media yang ada”.

Penggunaan kata-kata kotor juga termasuk dalam bentuk kekerasan psikis. Sebagai contoh jika seorang anak tidak mampu menyelesaikan perjaannya dengan baik, kemudian ayah atau ibunya melontarkan kata-kata seperti "Bodoh kamu!" atau "Gilaa kamu... Apa yang kamu lakukan!", maka ucapan-ucapan seperti ini sangat melukai hati anak dan akan berdampak negatif terhadap perkembangan kepribadiannya.

Dalam sebuah kutipan yang menarik dari UNESCO disebutkan bahwa "Disputes maybe inevitable, but violence is not. To prevent continued cycle of conflict, education must seek to promote peace and tolerance, not fuel hatred and suspicion" [perselisihan mungkin tidak dapat dihindari, tetapi kekerasan bisa. Dengan pendidikan diharapkan tertanam nilai-nilai perdamaian atau anti-kekerasan didalam diri para peserta didik dari tingkat dasar hingga perguruan tinggi, sehingga pada gilirannya mereka dapat mengedapankan nilai-nilai ini dalam berbagai aspek kehidupan didalam masyarakat tanpa melihat hambatan-hambatan kultural, agama, ras, kelompok, atau lain-lain]. Dari berbagai kasus kekerasan dan konflik yang mewarnai perjalanan bangsa Indonesia terutama pada akhir tahun 1990-an, dari konflik berdarah di Sambas dan Sampit, Ketapang, A mbon, Poso hingga berbagai wilayah lain di Indonesia, Begitu pula dengan radikalisme agama yang seringkali menggunakan kekerasan sebagai alat untuk 
mencapai tujuannya, seperti teror bom, pembakaran, dan sebagainya, tentunya memerlukan penanganan yang tepat. Dalam kenyataanya, telah banyak upaya dilakukan untuk mencegah terjadinya konflik-konflik ini, dari seminar-seminar tentang pencarian solusi konflik hingga dialog-dialog antara pemuka agama yang berbeda yang sampai saat ini kekerasan berbasis konflik tetap masih terjadi.

Pendidikan anti kekerasan (non-violence) mengindikasikan sebuah proses pembelajaran dan penanaman sikap-sikap mental yang menedepankan nilai-nilai positif nir-kekerasan dalam menghadapi setiap permasalahan sosial-keagamaan dalam masyarakat. Pendidikan ini tentunya mengubur dalam-dalam sikap egoistik (ananiya), tetapi sebaliknya mengedepankan kepentingan seluruh masyarakat daripada kepentingan individual atau kelompok untuk mencapai suatu kondisi harmonis di kalangan anggota masyarakat. Pendidikan anti kekerasan perlu dibangun dari nilai-nilai yang berkembang dalam masyarakat. Di antara nilai-nilai yang mungkin bisa dijadikan sebagai bahan dasar adalah nilai-nilai yang iambil dari agama, budaya, dan juga hak-hak asasi manusia yang universal. Berkenaan dengan yang pertama, hampir dalam semua agama di dunia mengajarkan prinsip-prinsip anti-kekerasan. Bahan dasar kedua adalah nilai-nilai budaya (cultural values). Istilah "budaya", dalam konteks ini merujuk kepada satu praktik dan kebiasaan masyarakat yang baik, yang telah diterima oleh masyarakat secara konsensus dan bersifat universal, tidak hanya menguntungkan satu pihak atau kelompok tertentu. Indonesia, dengan beragam kelompok etnik dan budaya ini, adalah sangat kaya dengan nilai-nilai budaya yang khas. Hampir semua kelompok etnik yang ada memiliki budaya tersendiri, yang masing-masing dari mereka mungkin memiliki kesamaan atau perbedaan budaya satu sama lainnya.

Bahan dasar yang terakhir adalah hak asasi manusia dan hak-hak ini merupakan esensi dari manusia itu sendiri, sebagaimana ditegskan oleh Jose Dioko, [Hak-hak asasi manusia lebih dari sekedar konsep-konsep hukum, ia adalah esensi manusia. Hak-hak inilah yang membuat seorang menjadi manusia. I tulah mengapa mereka disebut hak asasi manusia, menolaknya berarti menolak kemanusiaan manusia.] Hak-hak asasi manusia ini mencakup hak untuk hidup, kehormatan, dan mengembangkan diri sndiri. Atau lebih luas lagi ia mencakup apa yang disebut dengan al-khulliyyat al-khamsah (pemeliharaan atas agama, jiwa, akal keturunan dan kehormatan). Terkait dengan hak asasi manusia ini adalah hak budaya, ia juga merupakan bagian dari hak manusia. Hak untuk hidup bukanlah hidup seperti yang diinginkannya atau semaunya, tetapi hak untuk hidup sebagai seseorang yang berada dalam kultur komunitas tertentu, dalam satu cara hidup yang dianggap baik dan diterima oleh kultur itu. Dengan demikian, sikap empati terhadap kultur komunitas lain menjadi tumbuh, sehingga ketegangan dan konflik sosial berbasis perbedaan kultur bisa di cegah. Kesemua niai tersebut perlu di sosialisasikan dalam bentuk pembelajaran di institusi-institusi pendidikan, dari tingkat dasar hingga tingkat perguuruan tinggi, atau bahkan pada institusi-institusi pendidikan non-formal di masyarakat seperti pengajian, halaqah dan majlis taklim. Ini tidaklah berarti bahwa harus dimasukkan satu mata pelajaran atau mata kuliah tentang pendidikan anti-kekerasan secara khusus, tetapi bagaimana nilai-nilai atau perdamaian, yang terambil dari ajaran agama, budaya, dan hak asasi manusia, bisa masuk keseluruh mata pelajaran yang ada.

\section{Dampak Kekerasan Terhadap Kecerdasan Anak}

Sebagian besar orang tua yang memperlakukan anak-anak mereka dengan kekerasan menggunakan dalih memberikan peringatan atau hukuman agar anak tidak nakal dan menjadi 
penurut. Hukuman ataupun peringatan yang mereka berikan seringkali berupa hukuman fisik seperti menjewer, menampar, memukul, dan sejenisnya. Hal tersebut tentu menimbulkan rasa sakit baik secara fisik maupun psikis. Sebagaimana yang dikatakan oleh M onty P. Satiadarma bahwa jika orang tua memukul anak atau melakukan perlakuan fisik disertai kekerasan, anak akan merasakan sakit dan kemudian rasa sakit ini cenderung akan menyertai kondisi psikis anak pada perkembangan mereka selanjutnya.

Jamaal 'Abdur Rahman mengatakan bahwa sesungguhnya pendidikan yang mengacu pada sistem pemukulan dan kekerasan tidak akan menambahkan kepada anak didik, kecuali hanya kebodohan dan kebekuan pikiran. Bukan perbaikan yang didapat dari pemukulan dan kekerasan, melainkan akibat buruk yang menyisakan sakit dan luka pada diri anak. Sebenarnya kerugian tidak hanya diderita oleh anak saja, tapi orang tua juga akan merasakannya di kemudian hari.

Jika anak mengalami luka fisik akibat pemukulan dan sejenisnya, orang tua juga yang harus bertanggung jawab terhadap kesembuhannya. A palagi jika rasa sakit tersebut menyertai kondisi psikis anak, akibatnya akan fatal terhadap perkembangan kepribadiannya, dan orang tua juga yang akan merasakan dampaknya. Anak akan cenderung menentang, bahkan bisa juga mereka akan meniru perilaku keras tersebut di kemudian hari. Karena pada dasarnya, apapun yang dialami anak selama hidupnya akan masuk pada memori pikiran dan perasaannya yang tidak akan mudah terlupakan, apalagi jika peristiwa tersebut dirasakan sangat mendalam, termasuk juga kekerasan yang dialaminya.

$\mathrm{H}$ al tersebut sejalan dengan yang ditulis oleh Nurani Soyomukti bahwa menurut teori psikoanalisis, watak mental dari seseorang dibentuk oleh pegalaman-pengalaman masa lalu khususnya di masa anak-anak. Selain itu, M onty juga mengatakan bahwa anak akan senantiasa mengingat perlakuan orang tua mereka dimasa kecil, dan secara tidak disadari anak akan mengalami tekanan psikis berlebihan yang memungkinkannya mengalami gangguan emosional kelak.

Jelaslah bahwa kekerasan fisik terhadap anak membawa dampak yang tidak baik dalam perkembangan kepribadiannya. Jika orang tua menegur dan menghukum anak dengan pukulan ataupun tamparan dan sejenisnya, selain rasa sakit yang secara langsung dirasakan oleh tubuhnya, secara tidak langsung hal tersebut juga akan membekaskan luka dalam batinnya yang akhirnya dapat menimbulkan perasaan cemas, takut, dendam, psimis, kecewa dan sebagainya.

$\mathrm{Hal}$-hal eperti tersebut di atas tentu mengganggu perkembangan kecerdasan emosional spiritual anak. Orang tua yang harusnya memberikan perhatian dan kasih sayang, membimbing dan membantu anak mengembangkan kecerdasannya justru menyakiti mereka dengan perlakuan-perlkuan kasar. A palagi di masa-masa anak usia sekolah dasar, dimana mereka mulai menerima banyak pengaruh dari luar harusnya mereka mendapatkan dukungan dan bimbingan dari orang tua mereka. Pengetahuan dan pemikiran mereka berkembang pesat, daya ingat merekapun semakin kuat. Jika mereka diperlakukan dengan kekerasan pasti akan semakin menentang.

M uhammad Sa'id Mubayyadh menjelaskan bahwa:

Tidak boleh menggunkan pukulan fisik yang keras dan akan melukai pribadi anak serta membuatnya menunjukkan reaksi negatif, yang tercermin lewat tipu daya dan kecenderungannya untuk memusuhi keluarga dengan melakukan perilaku-perilaku negatif yang tidak disukai, sekadar untuk memulai pertentangan dengan kedua orang tua dan menentang otoritas mereka.

Hukuman berupa kekerasan fisik yang ditimpakan orang tua terhadap anak hanya akan merubah perilaku mereka untuk sementara saja. Seperti yang dijelaskan oleh Jane Elizabeth 
Allen dan Marlyn Cheryl bahwa saat anak-anak dihukum, keputusan mereka lebih sering berkenaan dengan cara menghindari hukuman, menentang orang dewasa atau menjadi 'penyenang' orang daripada memilih perilaku yang tepat. A nak melakukan perintah orang tua bukan karena kesadaran mereka tetapi lebih karena terpaksa dan hanya ingin menghindari hukuman kekerasan dari orang tua mereka.

Jamaal 'A bdur Rahman juga menjelaskan bahwa:

Keterpaksaan akan membuat jiwanya merasa sempit dan sulit mendapatkan kelapangan. Semangat membuat kreatifitasnya akan lenyap, cenderung pada sikap mal as, dan mendorongnya untuk suka berdusta dan melakukan kebusukan karena takut terhadap perlakuan suka memukul yang ditimpakan atas dirinya secara paksa. Pendidikan secara keras yang diterapkan terhadap dirinya mengajarinya untuk melakukan tipu muslihat dan penipuan sehingga lama-kelamaan akan menjadi kebiasaan dan pekerti bagi yang bersangkutan. Akhirnya, akan rusaklah nilai-nilai kemanusiaan yang seharusnya dijunjung tinggi olehnya.

Dampak yang ditimbulkan oleh tindak kekerasan orang tua sangat kompeks dan fatal. Kekerasan yang awalnya mereka pikir dapat mendisiplinkan dan dapat merubah perilaku anak menjadi penurut, yang terjadi malah sebaliknya, perilaku anak semakin buruk dan melenceng dari yang mereka harapkan. A nak menjadi sosok yang berjiwa beku, lemah kehendak, bertubuh kurus, labil emosinya, lemah tekadnya dan minim aktifitas dan gairah.

Orang tua seringkali tidak menyadari bahwa bentakan, cacian, hinaan bahkan paksaan akan berdampak buruk bagi perkembangan anak di masa yang akan datang. M eski hal tersebut tidak begitu terlihat sebagi bentuk kekerasan, tetapi sebenarnya akibatnya lebih berbahaya. $\mathrm{H}$ anya dengan sebuah perkataan yang tidak dikemas dengan baik, akan melukai hati anak yang selamanya akan membekas dalam diri mereka.

M enurut Zakiyah Darajat yang dikutip oleh Sokip menjelaskan bahwa kepribadian orang tua, sikap dan cara hidup mereka, merupakan unsur-unsur pendidikan yang tidak langsung, yang dengan sendirinya akan masuk ke dalam pribadi anak yang sedang berkembang itu. Jika orang tua memiliki kepribadian yang baik dan mendidik anak-anak mereka dengan benar, maka anak-anak merekapun akan bisa mengambil teladan dari mereka dan memiliki kepribadian yang baik pula. A kan tetapi jika orang tua sendiri tidak mampu bersikap baik di hadapan anakanak mereka seperti berbicara dengan nada keras dan membentak-bentak bahkan sampai mengeluarkan kata-kata kotor, maka tidak heran jika akhirnya anak-anak mereka juga berperilaku demikian.

Seringkali orang tua menganggap anak sebagai miniatur orang dewasa dan memperlakukan mereka sesuai yang diinginkannya, padahal anak masih membutuhkan ruang untuk tumbuh karena mereka juga makhluk yang memiliki kebebasan untuk memenuhi kebutuhan yang mereka perlukan dalam hidupnya. M eski orang tua merasa memiliki jiwa anak, tapi bukan berarti mereka bebas melakukan apa saja tanpa perduli pada hak dan kebebasan anak.

Jika pada kenyataannya orang tua lebih suka memaksa keinginannya dan mengharapkan anak menjadi manusia yang sempurna seperti yang mereka inginkan, pasti hal tersebut membuat jiwa anak merasa sakit dan tertekan. A palagi jika mereka melakukan sedikit kesalahan saja kemudian orang tua langsung melontarkan ancaman ataupun hinaan, tentunya hal tersebut sangat menyakitkan dan membuat mereka hancur bahkan bisa jadi putus asa.

Ibnu Khaldun menegaskan sebagaimana yang dikutip oleh Sa'id Mubayyadh bahwa kekerasan pada anak akan membuatnya menjadi lemah dan lari dari beban hidup. Paksaan dan tekanan yang dirasakan oleh anak bukan membuat mereka menjadi lebih baik dan penurut, 
tetapi hal tersebut malah akan membuat mereka patah semangat dan putus asa serta kehilangan kreatifitasnya. Sebagaimana perkataan Ibn Khaldun yang dikutip oleh M ubayyad bahwa:

Siapapun_baik orang yang terpelajar, budak, maupun pelayan-yang dibesarkan dengan tekanan dan paksaan, maka tekanan tersebut akan melumpuhkannya, menyempitkan kelapangan pribadinya hingga semangatnya hilang, membuatnya malas, membawanya pada kebohongan dan perbuatan licik (karena takut dikuasai oleh sesuatu), serta mengajarinya makar dan tipu daya. Lama-kelamaan hal ini menjadi kebiasaan hingga ia kehilangan jati diri insani yang dimilikinya.

Dari perkataan yang ditulis oleh Ibn Khaldun di atas jelas bahwa tekanan dan paksaan akan membawa dampak negatif pada diri anak. Yang seharusnya mereka bisa lebih dewasa secara emosional dan spiritualnya, dalam perkembangannya mereka justru mengalami hambatan dan gangguan. Secara emosional harusnya anak-anak yang telah memasuki usia sekolah dasar bisa meningkatkan motivasi dan semangatnya untuk berprestasi baik dalam bidang akademis maupun sosial. A kan tetapi dengan adanya tuntutan yang berlebihan, harapan yang terlalu tinggi dan paksaan dari orang tuanya, semangat mereka malah menjadi melemah, daya kreatifitasnya terbunuh dan yang lebih buruk lagi jika akhirnya mereka mulai berani berbohong ataupun berperilaku licik sebagai bentuk protes karena ketertekanan yang mereka alami.

A dapun dari segi spiritualnya, seharusnya anak mulai belajar memahami dan menghayati nilai-nilai kebenaran dalam agama yang diyakininya. Ketika mereka memasuki usia baliq, mereka telah memiliki kewajiban untuk menjalankan ajaran-ajaran agamanya. Harusnya keimanan mereka semakin mantap agar tidak mudah goyah ketika mereka menghadapi pengaruh-pengaruh dari lingkungan di sekitar mereka. Sudah tentu menjadi tanggung jawab orang tua untuk membimbing anak memantapkan keimanan dan prinsip hidup mereka. Tetapi jika kenyataannya yang mereka peroleh adalah perlakuan keras, tekanan dan paksaan maka perkembangan kecerdasan spiritual mereka akan terhambat.

Jika orang yang seharusnya menjadi panutan dan tempat berlindung malah memberinya perlakuan yang menyakitkan tentu membuat mereka bimbang dan tidak memiliki pegangan hidup yang jelas. Bagaimana mungkin mereka bisa melakukan ibadah dengan kesadaran penuh dari dirinya, jika apapun dilakukan karena terpasa sebagai pemuas keinginan orang tua saja. Sungguh fatal akibat yang ditimbulkan dari sikap keras dan memaksa atau mengekang yang dilakukan oleh orang tua pada anak mereka. Karena pada hakikatnya tidak hanya anak yang akan menderita, orang tuapun akan merasakan imbasnya di kemudian hari dengan melihat perkembangan kepribadian mereka yang semakin buruk dan melenceng dari proporsi kemanusiaan yang mereka impikan.

Selain tekanan dan paksaan yang tidak kalah membahayakannya adalah penggunaan kata-kata kotor dan cacian. "Anak yang sering mendengar perintah-perintah diiringi dengan suara keras dan bentakan, tidak bisa diharapkan untuk bicara dengan lemah lembut". Selain itu, "kata-kata yang kasar dan melukai perasaan serta menghina, akan berubah menjadi tikaman yang tertanam pada jiwa anak, sehingga menyakitkan dan menyebabkan kepedihan dan gangguan-gangguan padanya".

Anak yang terlalu sering dihina, dicaci, dan dibentak-bentak akan terpukul dan terluka. Mereka akan menjadi orang yang pesimis, putus asa, hilang semangat dan lemah kepribadiannya. Bagaimana tidak, jika orang tua yang harusnya memberikan kasih sayang, semangat dan dukungan malah membuat mereka terpojok dan terhina. 


\section{Pendidikan Anti Kekerasan di Lingkungan Keluarga dalam Perspektif Islam}

Islam menganjurkan orangtua agar menghargai anak-anak mereka dan memperlakukan mereka dengan baik serta tidak boleh menggunakan kata-kata kotor dalam mendidik anak-anak mereka. Sebagaimana firman Allah SWT:

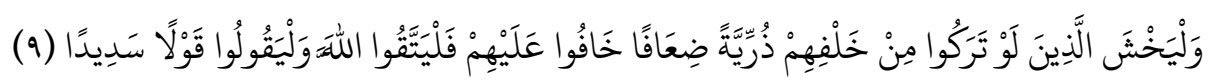

Artinya: "Dan hendaklah takut kepada Allah orang-orang yang seandainya meninggalkan di belakang mereka anak yang lemah yang mereka khawatir terhadap (kesejahteraan) mereka. Oleh sebab itu, hendaklah mereka bertaqwa dan hendaklah mereka mengucapkan perkataan yang benar."(Q.S. An-Nisa': 9).

Berdasarkan ayat tersebut jelaslah bahwa orang tua harus memperlakukan anak-anak mereka dengan baik dan jangan sampai mengeluarkan kata-kata kotor atau hinaan terhadap diri mereka. Kata-kata kotor yang terlontar secara sadar atau tidak akan masuk pada memori perasaan dan pikiran anak. Hal yang menyakitkan tersebut akan membekas dan selamanya teringat. Bukan tidak mungkin jika di kemudian hari mereka akan meniru kata-kata itu pada orang lain, karena apapun yang keluar dari orang tua akan sangat berpengaruh pada kepribadian anak di masa yang akan datang.

Dalam ayat lain dijelaskan dalam mendidik hendaknya dilakukan dengan baik dan juga tanpa kekerasan, sebagai mana disebutkan dalam al-Q ur'an antara lain dalam ayat berikut ini:

$$
\text { (r) (r).... }
$$

A rtinya: “... dan ucapkanlah kepada mereka perkataan yang mulia.”(Q.S. al-Isra'/17:23).

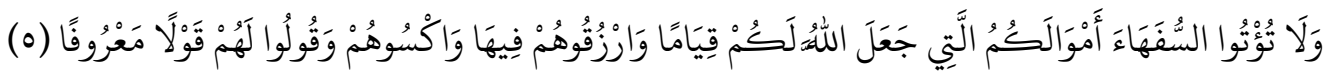

Artinya: "Dan janganlah kamu serahkan kepada orang-orang yang belum sempurna akalnya, harta (mereka yang ada dalam kekuasaanmu) yang dijadikan Allah sebagai pokok kehidupan. Berilah mereka belanja dan pakaian (dari hasil harta itu) dan ucapkanlah kepada mereka kata-kata yang baik. Ilah dan hendaklah mereka mengucapkan perkataan yang benar." (Q.S. al-N isa'/4:5)

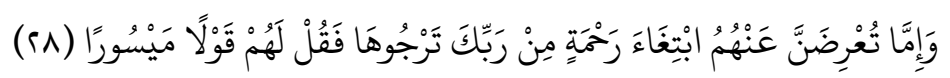

Artinya: "Dan jika kamu berpaling dari mereka untuk memperoleh rahmat dari Tuhanmu yang kamu harapkan, maka katakanlah kepada mereka ucapan yang pantas.” (Q.S. al-Isra'/17: 28)

Beberapa ayat di atas mengemukakan tentang berkomunikasi atau berkata-kata yang baik dan tidak membuat orang lain marah, yaitu dengan perkataan yang benar, perkataan yang pantas, perkataan yang mulia dan perkataan yang baik. Di samping itu, juga nada bicara seseorang itu juga harus dijaga, karena walaupun bicaranya dengan menggunakan kata-kata yang sopan, namun nadanya keras, maka hal itu juga akan membuat orang lain merasa sakit. Selain itu, raut muka ketika bicara juga perlu dijaga. Jangan sampai seseorang dalam setiap bertemu dengan orang lain menunjukkan raut muka yang masam. Jika dalam bicara atau berkata, seseorang menunjukkan raut muka yang masam, maka orang yang diajak bicara juga akan merasa tidak enak.

Maka dari itu, dalam bertingkah laku, mulai dari cara berjalan, cara bicara dan gaya ketika bertemu orang lain, harus dijaga sebaik-baiknya. Jangan sampai orang lain merasa sakit atau terluka karena sikap dan gaya yang kita lakukan. Hendaklah dalam bersikap itu, yang 
sederhana saja, jangan bergaya yang tidak perlu, dan hendaklah seorang yang berkhlak baik itu menundukkan kepala dalam berjalan, jangan berjalan dengan menengadahkan kepala, karena ibarat ilmu padi, makin berisi makin menunduk. Demikian juga manusia, apabila ilmunya tinggi, maka tentunya ia tidak lagi sombong dan selalu bersikap rendah hati.

\section{Simpulan}

Dari pembahasan di atas, dapat disimpulkan bahwa dampak kekerasan orang tua terhadap perkembangan kecerdasan emosional spiritual anak ini mengarah pada hal-hal yang negatif. Sadar atau tidak kekerasan yang dilakukan orang tua telah menanamkan kebencian dan rasa takut yang berlebihan pada diri anak. Kekerasan akan menanamkan sifat keras dan sikap kasar pada diri anak, membekaskan luka di hati anak hingga mereka dewasa. $\mathrm{H}$ al tersebut juga dapat menimbulkan kebimbangan dan kecemasan pada jiwa mereka. Selain itu, anak akan merubah perilakunya hanya untuk sementara, hanya sebagai penyenang belaka untuk menghindari kekerasan dari orang tua mereka sendiri. A nak juga kurang bisa sabar dan cepat terpancing emosi. Kekerasan tersebut secara tidak langsung juga membuat anak lebih memilih sifat negatif yang tercermin dalam kebohongan atau tipu muslihat. Kekerasan dalam bentuk apapun akan merusak kepribadian anak pada perkembangan anak di masa yang akan datang, baik perkembangan kecerdasan emosionl maupun spiritualnya.

Islam mengajarkan pendidikan yang bersifat anti kekerasan, apalagi dalam konteks mendidik anak usia dini, dilakukan dengan penuh kasih sayang. Banyak ayat al-Qur'an yang memerintahkan mendidik anak dengan kasih sayang kepada putra-putranya yang masih kecil. Bahasa qaulan layyinan, qaulan ma'rufan dan sebagainya merupakan perintah untuk mendidik dan berinteraksi dengan anak didik dengan penuh kasih sayang dan cara yang baik.

\section{Referensi}

Allen, Jane Elizabeth, M arilyn Cheryl. 2005. Construktive Childcare Provivers: Building The Best Environments For Preschool Children (Disiplin Positif M enciptakanDunia Penitipan Anak yang Edukatif Bagi Anak Pra-Sekolah), terj. I mam M achfud, Jakarta: Prestasi Pustakarya.

Departemen Agama Republik Indonesia. 1989.AI- Qur'an dan Terjemahnya, Semarang: CV. Toha Putra.

Gunarsa, Singgih D., Y.Singgih D.Gunarsa. 1991.Psikologi Praktis: Anak, Remaja dan Keluarga, Jakarta: Gunung Mulia.

Hasbullah. 2003.Dasar-dasar IImu Pendidikan (Umum dan Agama Islam), Jakarta: PT Raja Grafindo Persada.

M azhahiri, Husain. 1999. Pintar M endidik Anak, Jakarta: PT Lentera Basritama.

M oleong, Lexy J. 1990. M etode Penelitian Kualitatif. Bandung: Remaja Rosda Karya.

M uawanah, Elfi. 2004. Bimbingan Konseling. Jakarta: Bina IImu.

M ubayyadh, M uhammad Sa'id. 2006. Akhlak At Thiflu Al M uslim (Akhlak Anak M uslim), terj. A bdul Syukur dkk. Jakarta: Najla Pers.

M uhadjir, Noeng. 1998. M etodologi Penelitian Kualitatif, Yogyakarta: RakeSarasin. 
Rahman, Jamal 'Abdur. 2005. Athfaalul Muslimin, Kaifa Rabbahumun Nabiyyul Amin (Tahapan Mendidik Anak Teladan Rasulullah SAW), terj. Bahrun Abubakar Ihsan Zubaidi. Bandung: Irsyad Baitus Salam.

Satiadarma, M onty P. 2001. Persepsi Orang Tua M embentuk Perilaku Ana: Dampak Pygmalion di dalam Keluarga. Jakarta: Pustaka Populer O bor.

Shaleh, A bdul Qodir. 2003. A gama Kekerasan. Yogyakarta: PRISM ASH OPIE Press.

Soyomukti, Nurani. 2008. Pendidikan Berperspektif Globalisasi. Jogjakarta: A r-Ruzz M edia.

Thohir, Muhammad. "Pendidikan Tanpa Kekerasan (Telaah verbal abuse dalam Lingkungan Keluarga dan Sekolah)" dalam Ta'allum Jurnal Pendidikan Islam, vol.17. N o.1, Juni, 2007.

Uno, Hamzah B. 2006.Orientasi Baru Dalam Psikologi Pembelajaran. Jakarta: Bumi Aksara. 